\title{
Review paper \\ Polymers and volatiles: Using VOC analysis for the conservation of plastic and rubber objects
}

\author{
Katherine Curran, Matija Strlič
}

Centre for Sustainable Heritage, University College London, London, UK

There is an acknowledged need for improved conservation of plastic and rubber objects within collections, including improved methods of condition assessment, material identification, and better understanding of material degradation. This reflects the inherent instability and wide-ranging formulations of many such objects and also the relative lack of knowledge in this field. Analysis of volatile organic compounds (VOCs) is a useful method for understanding the chemical processes involved in polymer degradation and for the identification of materials. Conservators and curators have used odor analysis to identify historical plastics for many years, and techniques ranging from acid detection strips to laboratory-based techniques such as solid-phase microextraction-gas chromatography-mass spectrometry have been used to characterize plastic and rubber materials and to understand their degradation. VOC analysis also has potential as a technique for bulk material identification, as a complementary tool to spectroscopic analysis of the surface. A significant advantage of $\mathrm{VOC}$ analysis is its potential to be non-invasive, avoiding destructive sampling or even contact with an object. However, there is a greater potential for VOC analysis to be of benefit within conservation than is currently being exploited and significant scope for future research. In fields such as construction or waste management, there is also significant research into analysis of VOC emissions from plastic and rubber materials. The goal of this paper is to systematically review research from a range of fields including conservation, polymer degradation, and plastics recycling and it includes the use of VOC analysis to understand the causes of damage to plastic and rubber objects, to provide evidence of degradation and to monitor degradation progress, and to identify materials and distinguish between different formulations. Summaries of relevant studies are given, and volatile markers of object damage and polymer degradation and key volatile identifiers of a particular material are highlighted.

Keywords: Plastic, Rubber, Polymer, Modern materials, Volatile organic compounds

\section{Introduction}

Plastic and rubber objects bear witness to the modern age, expressing and enabling some very recognizable modern values: our reliance on technology, desire for convenience, and increasingly 'disposable' lifestyles. The use of synthetic polymers, in combination with plasticizers, stabilizers, dyes, and other additives has produced a wide range of materials, including moldable plastics and rubbers, both of which will be covered as part of this review. These materials have played a crucial role in the development of some historically significant technologies, such as airborne radar during WWII. They are also found in many beautiful pieces of modern art and design. The

Correspondence to: Katherine Curran, University College London, 14 Upper Woburn Place, Wc1H ONN London, UK. Email: k.curran@ucl.ac.uk preservation of plastics and rubbers in museums and galleries is therefore vital in deepening our understanding of twentieth century history, art, and design (Fig. 1).

Within collections, unstable plastics and rubbers often display visible degradation 'symptoms' within 5-25 years of acquisition (Shashoua, 2008, p. 152). The need for improved material identification, condition assessment, and degradation monitoring in the case of plastic objects was highlighted in the 2009 UK National Heritage Science Strategy Report (Williams, 2009, pp. 27-8).

Volatile organic compounds (VOCs) can be defined in various ways, for example, within the EU the term refers to organic substances with boiling points of less than or equal to $250^{\circ} \mathrm{C}$ at atmospheric pressure (European Parliament, 2004). In this review, this 




Figure 1 Celluloid hair comb, c.1910. Image credit: Colin Williamson

definition is somewhat extended to incorporate any organic compounds that can be detected either by the human olfactory system, or by gas chromatographicmass spectrometric (GC-MS)-based techniques, including those with boiling points above $250^{\circ} \mathrm{C}$. This includes the products of polymer degradation reactions and additives such as phthalate plasticizers, as both chemical processes, such as hydrolysis and oxidation, and physical processes, such as the migration of additives from the bulk to the surface of an object, are of interest within conservation.

Analysis of VOC emissions can provide valuable information regarding degradation processes that are ongoing within a plastic or rubber object. In addition, the VOCs emitted by such objects are characteristic of the materials of which they are composed (LattuatiDerieux et al., 2012). The use of VOC emissions in the form of odor analysis for the purposes of identifying historical plastic materials has been used in conservation for some time. In a 1988 publication, Mossman (1988) described the characteristic emissions of Celluloid (camphor smell) and Bakelite (carbolic soap smell), and more wide-ranging odor descriptions have been published by Williamson (1999) and Shashoua (2008, pp. 119-20) more recently. Studying VOC emissions from historical plastic and rubbers is also relevant as it has been shown that emissions from such objects, particularly acetic acid and $\mathrm{NO}_{\mathrm{x}}$ can have a damaging impact on other materials (Curran et al., 2013).

The value of VOC analysis for understanding the degradation of historical plastics is well-known within conservation. Low technology methods such as the use of the acid detection strips (A-D strips) developed by the Image Permanence Institute have proved to be a useful method of assessing the extent of active degradation in cellulose acetate (CA) photographic film and negatives (Bigourdan \& Reilly, 2000; Image Permanence Institute, 2001; Shashoua, 2008, pp. 196-201). A-D strips contain an acid/base indicator and undergo color changes when exposed to different concentrations of acetic acid. A color code can be used to assess degradation and give recommendations for action such as changes to storage conditions or the need for duplication. Similar techniques, involving the adsorption of acid/base indicators onto paper or polymeric substrates, have also been used to detect acidic emissions from both CA and cellulose nitrate (CN) objects (Fenn, 1995; Harthan et al., 1997). Techniques such as GC-MSbased analysis which require more complex instrumentation have also been used within conservation for material identification and to understand degradation. These techniques will be described in more detail in a later section, and the majority of the studies reviewed in this paper make use of such analysis. Recent research on VOCs emitted from heritage materials of natural origin has shown that identification and estimation of material stability are both possible and degradomics was defined as the field of research into degradation products of an object based on inductive knowledge discovery (Strlič et al., 2009).

In addition, there is also a substantial body of literature from outside the field of conservation, describing the VOC emissions that are the result of the degradation of plastics and rubber. Standard methods for studying loss of volatiles from plastics date back to the 1950s (ASTM International, 2011) and VOC monitoring is now routinely used for quality control purposes within the plastics processing industry (Albertsson et al., 2006). Analysis of VOC emissions from plastic and rubber materials is a large area, covering many different disciplines and this paper does not attempt to provide a comprehensive review of this topic. The purpose of this review is to bring together more recent research within conservation and heritage science and also from other domains such as construction, waste management, and polymer science in order to explore how VOC analysis can be used in conservation to better understand polymer degradation and thus the physical damage observed in plastic artifacts and artworks.

This review is divided into three sections. The first will present work in which connections between VOC emissions, polymer degradation, and observed 'symptoms' of deterioration have been explored. The second section reviews cases where VOC analysis has been used to provide evidence of degradation and to monitor degradation progress. The third section gives examples of the use of VOC analysis for polymer identification and to distinguish between different plastic formulations.

Given that some of the work reviewed here comes from the fields outside of cultural heritage such as plastics recycling, some of the analysis, in particular, any pyrolysis (Py)-GC-MS analysis, and the accelerated degradation described have been performed at 
high temperatures. This has been done for various reasons, for example, in order to mimic relevant conditions such as those used during material processing. The results from such studies should therefore be interpreted with care. However, such work provides analysis of fundamental degradation processes and characteristic VOC emissions and is thus a valuable source of information regarding the deterioration of plastic and rubber objects in general. The purpose of this review is to give a sense of the scope of this rich area, and to prompt ideas for future research.

\section{Analytical techniques}

Several different analytical techniques are mentioned in this review and the following table describes briefly what is meant by each. The descriptions below are taken directly from the literature cited and in some cases, e.g. thermal desorption-GC-MS (TDGC-MS) may not be suitable as descriptions of these techniques as generally used (Table 1).

Some of the studies referred to in this review involved quantitative analysis, using calibration standards to calculate the amount of a particular VOC emitted from a known mass of plastic sample (e.g. Hall \& Patel, 2006; Vilaplana et al., 2010). In most cases however, qualitative analysis was performed and relative amounts or relative increases or decreases in VOC emissions were reported.

While the analysis of VOC emissions from historical plastic objects can provide valuable and detailed information regarding material composition and degradation processes, it is important to note that several of the techniques used for this type of analysis require destructive sampling. For example, while PyGC-MS has been used successfully as a tool for the identification of plastics in collections (Schilling et al., 2012; Sutherland et al., 2012), it requires pyrolysis of a small sample at high temperatures $\left(>600^{\circ} \mathrm{C}\right)$ (Stuart, 2007, p. 303). Techniques such as microwave-assisted extraction (MAE)-GC-MS, simultaneous pyrolysis methylation (SPM)-GC-MS, and thermogravimetric analysis (TGA)-GC-MS are similarly destructive. GC-MS-based techniques can be time-consuming and require both large and expensive analytical equipment and specialized knowledge for data interpretation - resources that are often unavailable to conservators.

For these reasons, tools such as spectroscopic techniques are often the preferred techniques for understanding the composition and condition of plastic objects in collections, as they provide rapid results non-invasively. For example, Fourier transform

Table 1 Analytical techniques covered within this review

\begin{tabular}{|c|c|c|c|}
\hline Abbreviation & Full name & Description & $\begin{array}{l}\text { Sample } \\
\text { reference }\end{array}$ \\
\hline $\begin{array}{l}\text { DI-SPME-GC- } \\
\text { MS }\end{array}$ & $\begin{array}{l}\text { Direct immersion solid-phase } \\
\text { microextraction-gas } \\
\text { chromatography/mass spectrometry }\end{array}$ & $\begin{array}{l}\text { Absorption of VOCs onto polymer-coated fiber placed } \\
\text { in drop of solvent on object surface, followed by } \\
\text { injection of fiber into GC-MS and desorption at high } \\
\text { temperature }\end{array}$ & Ormsby (2005) \\
\hline FLEC & Field and Laboratory Cell technique & $\begin{array}{l}\text { FLEC is tightened onto surface, synthetic air pumped } \\
\text { through cell. VOCs are adsorbed onto Tenax in tubes } \\
\text { followed by thermal desorption (TD) into GC-MS }\end{array}$ & $\begin{array}{l}\text { Lundgren et al. } \\
\quad(1999)\end{array}$ \\
\hline HS-GC-MS & $\begin{array}{l}\text { Headspace-gas chromatography-mass } \\
\text { spectrometry }\end{array}$ & $\begin{array}{l}\text { VOCs collected from head space above sample in } \\
\text { sealed vessel using gas tight syringe followed by } \\
\text { injection into GC-MS }\end{array}$ & $\begin{array}{l}\text { Shashoua } \\
\text { (2001) }\end{array}$ \\
\hline MAE-GC-MS & $\begin{array}{l}\text { Microwave-assisted extraction-gas } \\
\text { chromatography-mass spectrometry }\end{array}$ & $\begin{array}{l}\text { Extraction of VOCs into solvent by heating in } \\
\text { microwave, followed by injection into GC-MS }\end{array}$ & $\begin{array}{l}\text { Vilaplana et al. } \\
\qquad(2010)\end{array}$ \\
\hline Py-GC-MS & $\begin{array}{l}\text { Pyrolysis-gas chromatography-mass } \\
\text { spectrometry }\end{array}$ & $\begin{array}{l}\text { Rapid heating (pyrolysis) of sample followed by direct } \\
\text { introduction of sample vapor to GC-MS }\end{array}$ & $\begin{array}{l}\text { Sutherland } \\
\text { et al. (2012) }\end{array}$ \\
\hline SPM-GC-MS & $\begin{array}{l}\text { Simultaneous pyrolysis methylation-gas } \\
\text { chromatography-mass spectrometry }\end{array}$ & $\begin{array}{l}\text { Polymer is flash heated with tetramethylammonium } \\
\text { hydroxide (TMAH) to hydrolyze and methylate } \\
\text { polymer before analysis with GC-MS - an example of } \\
\text { derivatization pyrolysis }\end{array}$ & $\begin{array}{l}\text { Thiébaut et al. } \\
\text { (2009) }\end{array}$ \\
\hline SPME-GC-MS & $\begin{array}{l}\text { Solid-phase microextraction-gas } \\
\text { chromatography-mass spectrometry }\end{array}$ & $\begin{array}{l}\text { Absorption of VOCs in immediate environment of object } \\
\text { onto polymer-coated fiber followed by injection of } \\
\text { fiber into GC-MS and desorption at high temperature }\end{array}$ & $\begin{array}{l}\text { Curran et al. } \\
\text { (2013) }\end{array}$ \\
\hline TD-GC-MS & $\begin{array}{l}\text { Thermal desorption-gas } \\
\text { chromatography-mass spectrometry }\end{array}$ & $\begin{array}{l}\text { Powder abraded from plastic surface aspirated into } \\
\text { glass cartridges placed directly into adapted GC } \\
\text { injector chamber* }\end{array}$ & $\begin{array}{l}\text { Carlsson et al. } \\
\quad(1999)\end{array}$ \\
\hline TGA-GC-MS & $\begin{array}{l}\text { Thermogravimetric analysis and gas } \\
\text { chromatography-mass spectrometry }\end{array}$ & $\begin{array}{l}\text { Samples are heated in a TGA unit. The effluent from the } \\
\text { TGA unit is then sent to a GC-MS }\end{array}$ & $\begin{array}{l}\text { Kwon \& } \\
\text { Castaldi } \\
(2009)\end{array}$ \\
\hline
\end{tabular}

*The description given here of TD-GC-MS is unusual, and describes the use of TD-GC-MS as performed by Carlsson et al. (1999). Commonly, TD-GC-MS involves collection of VOCs onto a tube containing an absorbant material such as Tenax, followed by desorption at high temperature from a thermal desorber into the GC-MS. 
infrared (FTIR) spectroscopy, near-infrared, and Raman spectroscopy have already proved to be very useful tools for material identification (Keneghan et al., 2012). However, VOC analysis is a valuable complementary technique, which can be used to identify particular additives and degradation compounds present in low concentrations, in addition to the base polymer. Techniques such as solid-phase microextraction-GC-MS (SPME-GC-MS), which involve the adsorption of the VOC emissions onto a polymercoated fiber do not necessarily require destructive sampling and have already been used onsite in museum collections as a non-invasive method of analyzing the VOC emissions from historical wax objects (Lattuati-Derrieux et al., 2008). It is clear therefore that further investigation of non-invasive techniques such as SPME-GC-MS, the development of new methods for VOC analysis that are cheap and portable, and the development of techniques and resources for data interpretation that do not require specialized knowledge are areas of research that would enable the valuable chemical information provided by VOC analysis to be more widely used within conservation.

\section{Which materials?}

In order to prepare this review, it was necessary to identify the materials that have been well-documented as presenting significant problems within collections: $\mathrm{CA}, \mathrm{CN}$, poly(vinyl chloride) (PVC), and polyurethanes (PUR). CA and CN are some of the earliest synthetic plastics and the observed instability of objects made of these materials is partly a consequence of their age, but also a reflection of the fact that early plastic formulations were experimental and displayed a lack of knowledge of plastic stabilization.

In addition, a selection of other materials will be discussed. These materials were chosen based on surveys completed as part of the Preservation Of Plastic ARTefacts (POPART) project (Keneghan et al., 2012) and other reports from the Victoria and Albert (V\&A) Museum (Then \& Oakley, 1993), the Science Museum, London (Mossman, 1991), the British Museum (Shashoua \& Ward, 1995), and a study of plastics in archives (Calmes, 1991).

Based on the information contained in these studies regarding the materials that are most at risk, and those that are found in collections most frequently, a decision was made to focus within this review on seven materials, in addition to the four mentioned above. Overall, the materials include specific polymer types: CA, CN, PVC, poly(methyl methacrylate) (PMMA), polystyrene (PS), Bakelite, and other formaldehyde-based polymers and polyethylene (PE), and broader polymer families: PURs, polyesters, nylons, and rubbers. The terms 'rubber' and 'elastomer' can often be used interchangeably, so it is worthwhile defining what is meant by rubber in this context. In this review, 'rubber' is taken to include natural rubber, synthetic hydrocarbon-based rubbers, and silicone rubber, including both cross-linked and non-cross-linked materials.

\section{Damage to plastic and rubber objects - What can VOC analysis tell us?}

VOC analysis can be a useful tool for understanding the degradation of plastic and rubber artifacts and informing preventive conservation decisions. To achieve this, it is necessary to understand how VOC emissions can be related both to material degradation (incorporating chemical degradation such as polymer chain scission and also physical degradation such as loss of additives) and to the macroscopic signs of degradation observed in an object, sometimes referred to as 'damage' (Luxford et al., 2013). In some of the studies reviewed here, the authors have described both the analysis of volatile emissions and the physical changes observed in the object as it degrades, making it possible to probe these relationships. The table below summarizes the results of such studies (Fig. 2).

In the first example, a study of PVC samples used for outdoor construction demonstrated direct links between VOC emissions, observed damage, and the cause of degradation (Carlsson et al., 1999). The studied samples were commercial materials, which following chemical analysis were found to contain $5 \%$ of a methyl methacrylate (MMA)/butyl acrylate copolymer impact modifier, $10 \mathrm{wt} \% \mathrm{TiO}_{2}$, and a tin stabilizer $\left(0.18 \mathrm{wt}^{\%} \%\right)$. These samples were not plasticized, unlike many PVC samples found within museum collections. Differences were observed in the VOC emissions from samples that had been exposed to sunshine in Ottawa for 11 years, and samples that had not been exposed to the sun. The sun-exposed samples emitted a wider range of compounds, and of particular interest is the
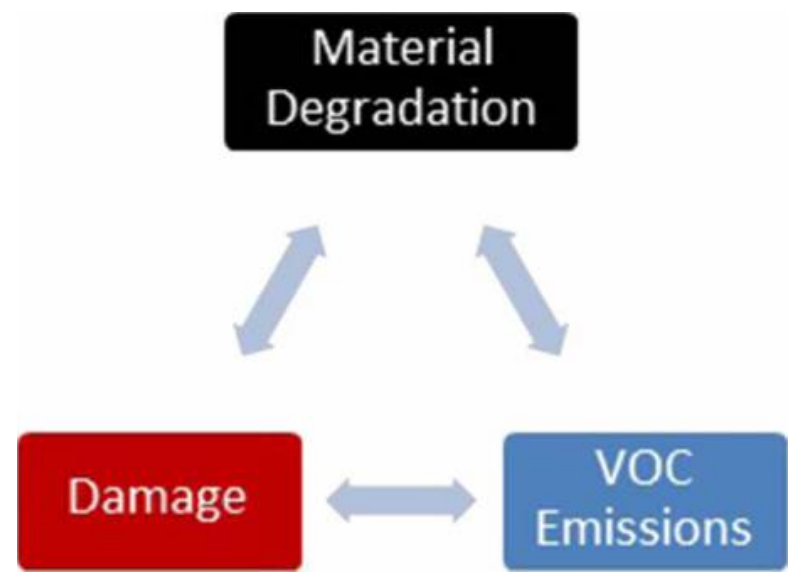

Figure 2 The figure illustrates how material degradation, macroscopic damage, and VOC emissions are inter-related. VOC analysis can therefore provide information about both material degradation and object damage. 
Table 2 Summarized results of reviewed research showing relationships between perceived damage to objects, vOC emissions, and polymer degradation

\begin{tabular}{|c|c|c|c|c|c|c|c|}
\hline Polymer & Object & Analytical method & Perceived damage & VOC emissions & Degradation type & Notes & Reference \\
\hline$\overline{P V C}$ & $\begin{array}{l}\text { Outdoor construction } \\
\text { materials }\end{array}$ & $\begin{array}{l}\text { Thermal } \\
\text { desorption-GC-MS }\end{array}$ & Chalking & $\begin{array}{l}\text { Chlorinated compounds, } \\
\text { e.g. 1-chlorobutane, } \\
\text { 1,1-dichloroacetone }\end{array}$ & Photolytic & $\begin{array}{l}\text { Chlorinated compounds are } \\
\text { result of exposure to sunlight }\end{array}$ & $\begin{array}{l}\text { Carlsson et al. } \\
\text { (1999) }\end{array}$ \\
\hline CA & $\begin{array}{l}\text { Sculpture (Naum } \\
\text { Gabo, Construction } \\
\text { in Space: Two } \\
\text { Cones, 1927) }\end{array}$ & Pyrolysis-GC-MS & $\begin{array}{l}\text { Darkening, sculpture had } \\
\text { shattered in some places, } \\
\text { some distortion }\end{array}$ & $\begin{array}{l}\text { Acetylated } \\
\text { anhydrosugars, AMF }\end{array}$ & Deacetylation & $\begin{array}{l}\text { AMF concentrations decrease } \\
\text { with increasing deacetylation } \\
\text { of plastic }\end{array}$ & $\begin{array}{l}\text { Sutherland } \\
\text { et al. (2012) }\end{array}$ \\
\hline $\begin{array}{l}\text { Natural rubber } \\
\quad \text { (polyisoprene) }\end{array}$ & $\begin{array}{l}\text { Natural rubber } \\
\text { samples }\end{array}$ & Head space-GC-MS & Rancid odor, smoky odor & $\begin{array}{l}\text { Carboxylic acids, } \\
\text { aromatic compounds, } \\
\text { e.g. ethylbenzene }\end{array}$ & Microbial & $\begin{array}{l}\text { Higher concentrations of low- } \\
\text { molecular weight acids and } \\
\text { aromatic compounds found in } \\
\text { malodorous samples }\end{array}$ & $\begin{array}{l}\text { Hoven et al. } \\
\quad(2003)\end{array}$ \\
\hline PUR & U-matic videotapes & $\begin{array}{l}\text { Solid-phase } \\
\text { microextraction } \\
\text { (SPME)-GC-MS }\end{array}$ & Strong odor & $\begin{array}{l}\text { Carboxylic acids, } \\
\text { furanones }\end{array}$ & $\begin{array}{l}\text { Thermo-oxidative or } \\
\text { hydrolytic }\end{array}$ & $\begin{array}{l}\text { Strong odors linked to high levels } \\
\text { of acids and furanones }\end{array}$ & $\begin{array}{l}\text { Thiebaut et al. } \\
\text { (2007) }\end{array}$ \\
\hline PUR & PUR-ester foam & $\begin{array}{l}\text { SPME-GC-MS; } \\
\text { Py-GC-MS }\end{array}$ & $\begin{array}{l}\text { Weakening, discoloration, } \\
\text { formation of white crystals }\end{array}$ & $\begin{array}{l}\text { Toluene diamine (TDA) } \\
\text { isomers, adipic acid }\end{array}$ & Hydrolytic & $\begin{array}{l}\text { Increased concentrations of TDA } \\
\text { isomers and adipic acid with } \\
\text { increased degradation }\end{array}$ & $\begin{array}{l}\text { Lattuati- } \\
\text { Derrieux } \\
\text { et al. (2011) }\end{array}$ \\
\hline PUR & PUR-ether foam & $\begin{array}{l}\text { SPME-GC-MS; } \\
\text { Py-GC-MS }\end{array}$ & $\begin{array}{l}\text { Discoloration, cracking, } \\
\text { crumbling }\end{array}$ & Glycol derivatives & Photolytic & $\begin{array}{l}\text { Increased concentrations of } \\
\text { glycol derivatives correspond } \\
\text { to increased degradation }\end{array}$ & $\begin{array}{l}\text { Lattuati- } \\
\quad \text { Derrieux } \\
\text { et al. (2011) }\end{array}$ \\
\hline Nylon & Nylon 6.6 fabrics & Chemical analysis* & Yellowing & $\begin{array}{l}\text { Pyrroles, dialdehydes, } \\
\text { diketones }\end{array}$ & Photolytic & $\begin{array}{l}\text { Yellowing not observed } \\
\text { immediately, only after storage } \\
\text { over months }\end{array}$ & $\begin{array}{l}\text { Marek \& Lerch } \\
\quad(1965)\end{array}$ \\
\hline CA & Laminated documents & SPME-GC-MS & $\begin{array}{l}\text { Decreased solubility in } \\
\text { organic solvents - } \\
\text { adjustments to } \\
\text { delamination treatment } \\
\text { required }\end{array}$ & Phthalic anhydride & $\begin{array}{l}\text { Deacetylation and } \\
\text { plasticizer } \\
\text { decomposition }\end{array}$ & & $\begin{array}{l}\text { Ormsby } \\
(2005)\end{array}$ \\
\hline
\end{tabular}

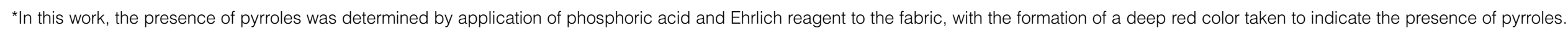


fact that the sun-exposed PVC was found to emit chlorinated compounds such as 1-chlorobutane and 1,1-dichloroacetone that were not emitted from the non-irradiated sample. Daylight-exposed PVC materials are known to undergo 'chalking', or the formation of a white powder on the surface which leads to noticeable material loss over time. This work showed a direct link between this chalking, exposure of the plastic to daylight, and the emission of chlorinated

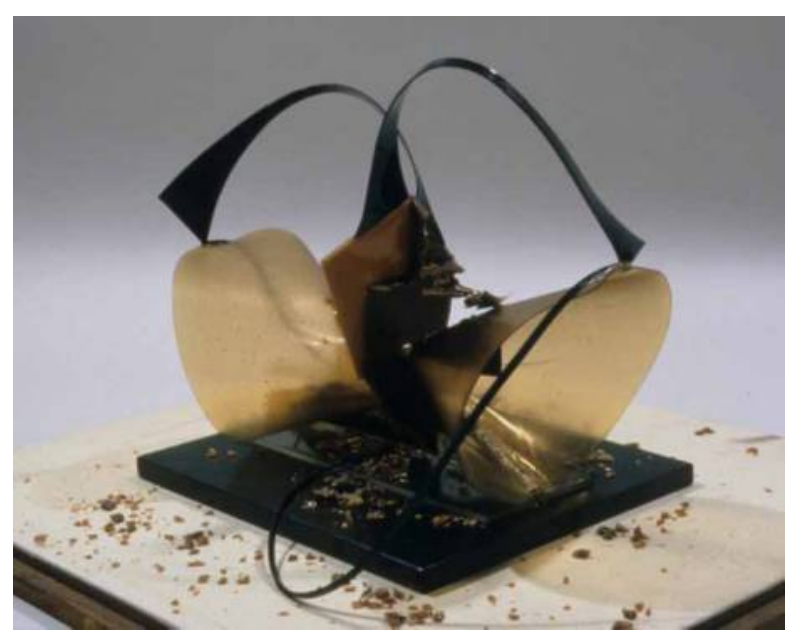

Figure 3 Construction in Space: Two Cones, condition in 2001. The Work of Naum Gabo @Nina and Graham Williams. Reproduced with permission. Photograph: Joe Mikuliak
VOCs. Scanning electron microscopy images of the daylight-exposed material show a very granular surface, while the non-irradiated sample was significantly smoother. This is a particularly interesting example, showing that VOCs may be characteristic of the type of degradation (although it should be noted that the impact of ultraviolet (UV) radiation on heritage materials is well-known within conservation and that polymer degradation initiated by exposure to UV radiation from sunlight is unlikely to be an issue within museums due to filtering). As a general principle, however, knowledge of the causes of degradation provides useful information regarding storage and display conditions (Table 2).

In another study, the severe deterioration observed in the CA-based parts of the Naum Gabo sculpture Construction in Space: Two Cones (Fig. 3) was shown to be linked to detected levels of acetylated anhydrosugars and 5-acetoxymethylfurfural (AMF) (Sutherland et al., 2012). AMF is formed from the pyrolysis of acetylated material and the levels of AMF were found to be much lower in degraded parts of the sculpture than in non-degraded reference materials.

A 2007 study of the VOCs emitted by naturally aged ester-based PUR U-matic videotapes from the Institut National de l'Audiovisuel demonstrated links between VOC emissions and odors reported from the tapes

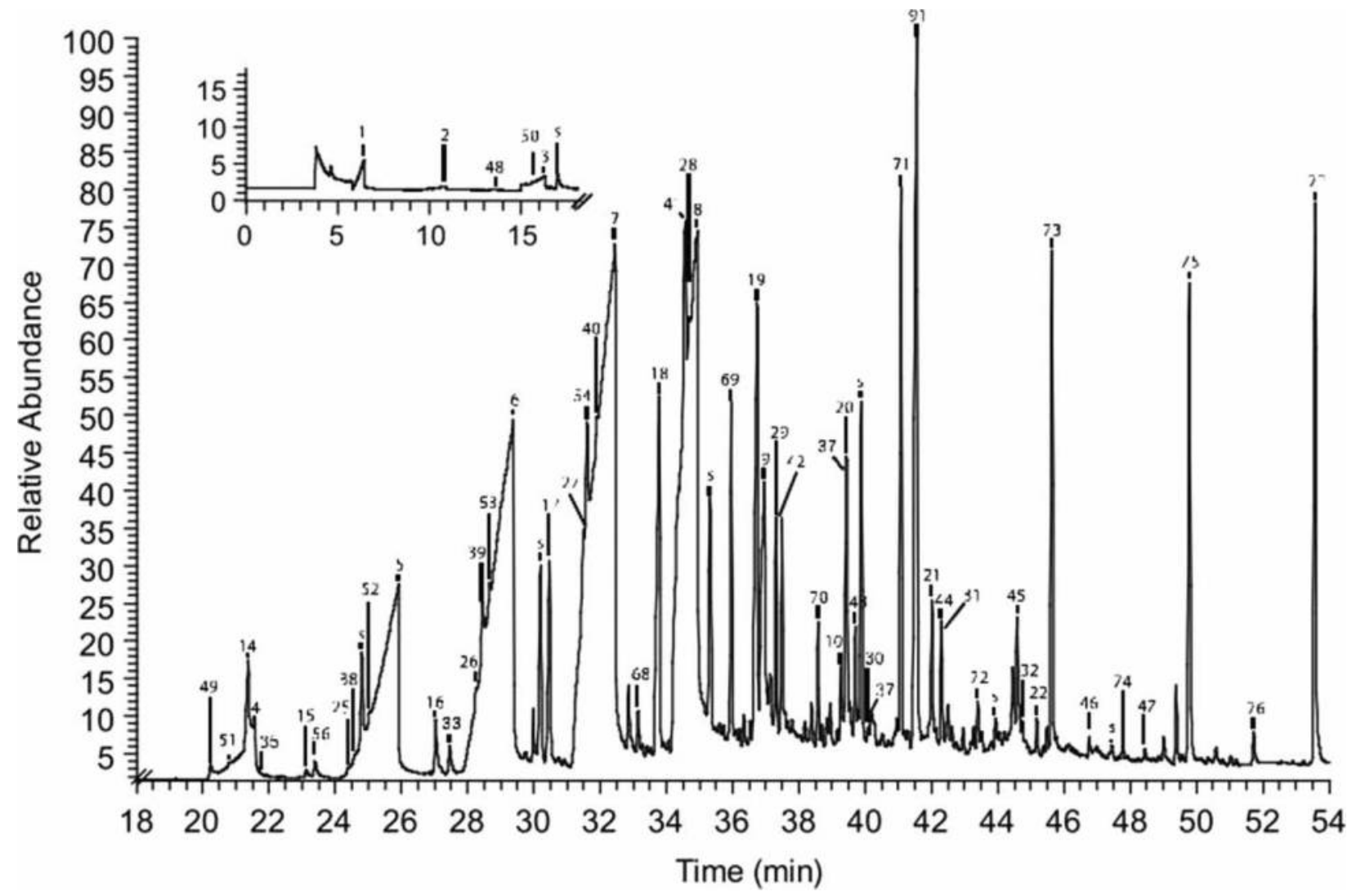

Figure 4 SPME-GC-MS chromatogram of U-matic tape sample showing the presence of, e.g. heptanoic acid (6) and octanoic acid (7). Reprinted from Thiebaut et al. (2007) with permission from Elsevier. 
(Thiebaut et al., 2007). The tapes had been stored for 12-25 years at room temperature in non-air-conditioned storage rooms. Information regarding visual signs of degradation was not provided. Using headspace SPME-GC-MS, additives, antioxidants, residual solvents, phthalates, and also series of carboxylic acids, furanones, ketones, aldehydes, and alkanes were identified (Fig. 4). An odor was detected from several of these tapes and to further study this, the samples were ranked by a panel of 10 people, in terms of the perceived strength of the odor. Samples whose chromatograms displayed high concentrations of carboxylic acids and furanones were marked out by the panel as having stronger odors than other samples, which indicates that these compounds are likely to be the cause of the reported odors. Carboxylic acids and furanones may be products of the thermo-oxidative or hydrolytic degradation of the PUR or of other copolymers or additives contained within the tapes.

A study of the components that cause bad odors in natural rubber samples highlighted low-molecular weight acids such as acetic acid, propionic acid, butyric acid, and valeric acid as the main causes of the observed rancid odor, with increasing levels of these acids found in increasingly malodorous samples (Hoven et al., 2003). Aromatic compounds such as ethylbenzene and xylene were found in samples with a smoky odor and sulfur-based compounds such as thiophene and thiazole were also detected from some of the samples. The authors suggest that the carboxylic acids formed are products of the microbial breakdown of non-rubber components in the samples.

Identifying the causes of problematic odors makes it easier to suggest possible remedies. For example, the use of adsorbents such as activated carbon which are known to adsorb carboxylic acids could potentially be used to reduce odors from materials such as natural rubber or PURs (Shashoua, 2008, pp. 196-201).

Links between the condition of PUR foams, VOC emissions, and hydrolytic degradation were demonstrated in a 2011 study, which showed that the degradation of ester-based PUR foams at $90^{\circ} \mathrm{C}$ and $50 \%$ relative humidity led to weakening and darkening of the foams in addition to increased levels of toluene diamine isomers and the presence of white crystals which were identified as adipic acid (LattuatiDerrieux et al., 2011) (Fig. 5).

SPME-GC-MS analysis of ether-based PUR foams as part of the same study showed increased concentrations of glycol derivatives upon increased photolytic (excluding UV) degradation. Discoloration, cracking, and crumbling of the foams were also observed. This work clearly shows the connections between VOC emissions, the chemistry of polymer degradation, and observed macroscopic damage and could potentially inform storage and display decisions. For example, the detection of the products of photolytic degradation from samples of PUR would suggest that dark storage would be beneficial.

A 1965 study by Marek \& Lerch (1965) investigated the relationships between the yellowing of nylon samples, photodegradation, and the production of pyrroles and carbonyl compounds. Chemical tests, such as the Ehrlich reaction identified the presence of pyrroles and carbonyl-based compounds such as dialdehydes and diketones in samples of nylon 6.6 that had been exposed in a Fade-Ometer for 144 hours at $50^{\circ} \mathrm{C}$. A Fade-Ometer is a unit used for studying the effect on textiles and inks of accelerated light aging. After storage in the dark for several months, yellowing of the exposed fabrics was also observed. The degradation products reported here were not detected as volatile emissions, however, work by Groning \& Hakkarainen (2001) showed that SPMEGC-MS analysis can also be used to monitor the formation of carbonyl-based compounds from samples of nylon 6.6. In the latter work, levels of carboxylic acids, assumed to be produced through oxidation of dialdehydes, increased with increased thermoxidative degradation, suggesting that VOC analysis could also be used to further understand the observed yellowing of nylon fabrics.

Deterioration of CA lamination films could be linked to the presence of phthalic anhydride in a study of laminated documents relating to the Louisiana Purchase (Ormsby, 2005). Although the author does not report visual signs of damage, it was known that the laminated films had deteriorated due a change in solubility which required adjustments to delamination treatment for repair or exhibition purposes. Phthalic anhydride is a degradation product of phthalate plasticizers with a boiling point of $295^{\circ} \mathrm{C}$ and is a white solid at room temperature. It therefore does not fall under the common definition of a VOC. However, given that it is detectable using GC-MS-based techniques and provides useful information regarding the degradation of phthalatebased plasticizers, it is considered of interest within this review. Phthalic anhydride was only detected in early lamination films that displayed a change in solubility, which is likely a result of the deacetylation of $\mathrm{CA}$ and the formation of cellulose, which may affect the compatibility of the phthalates with the material and lead to their deterioration. Although indirectly linked to the polymer degradation process, detection of phthalic anhydride in phthalate-containing plastics is potentially a useful indicator of the deterioration of the object and a change in its physical properties. 


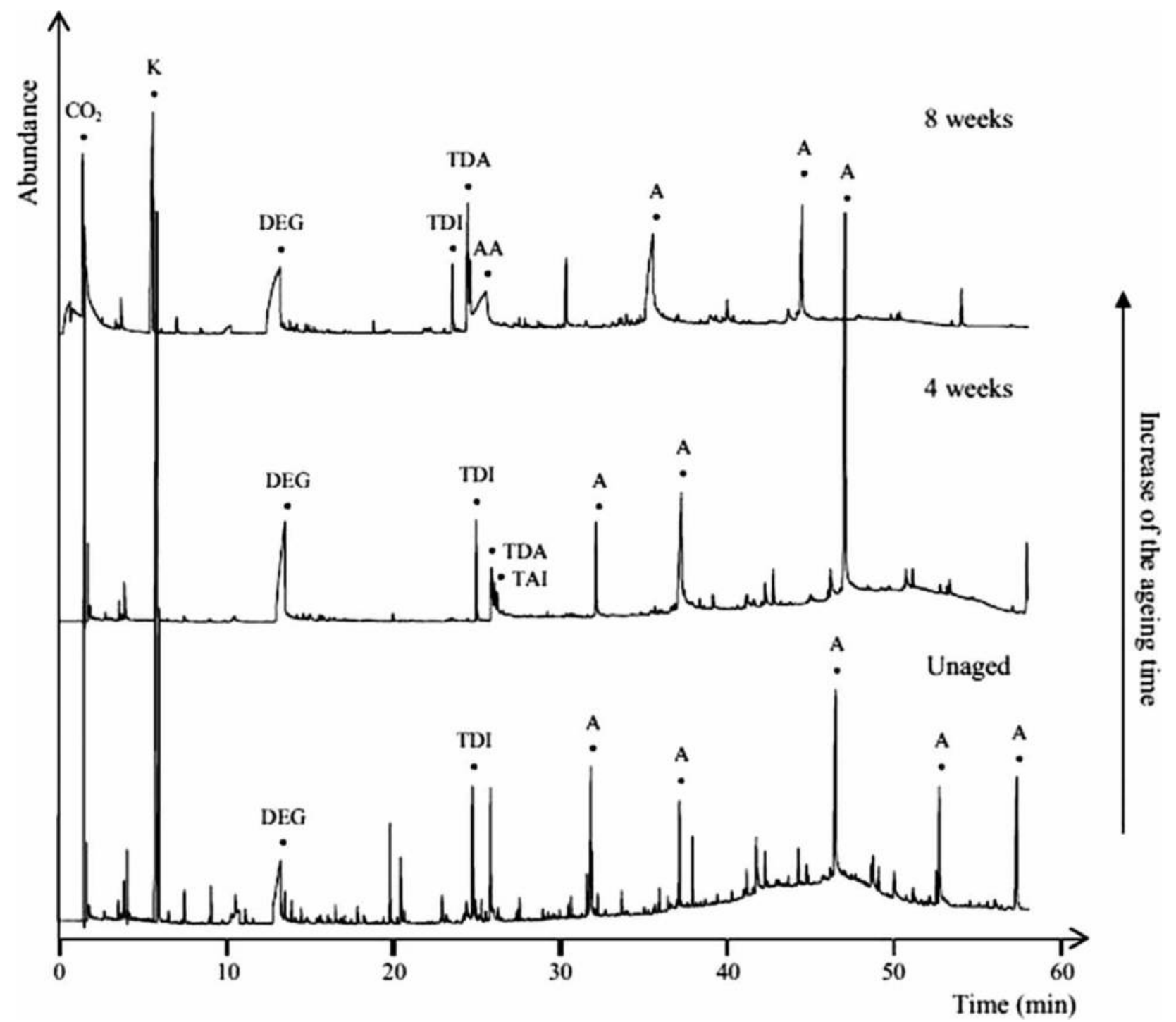

Figure 5 Chromatogram showing results of Py-GC-MS analysis of artificially degraded polyester-based PUR foams showing increase in toluene diamine isomers (TDA) and adipic acid (AA) with increased degradation time. Reprinted from LattuatiDerrieux et al. (2011) with permission from Elsevier.

\section{Using VOC analysis to understand polymer degradation}

The following section reviews several studies that have reported using VOC emissions to understand polymer degradation. In some cases, VOC analysis simply provides evidence that an object is degrading. In others, the authors have used specific VOC markers to monitor the progress of degradation. The table below summarizes the results of these studies (Table 3).

In work by Hakkarainen et al. (1997) SPME-GCMS analysis of PE films that had been exposed to UV radiation $(\lambda=280-359 \mathrm{~nm})$, and then heated for five weeks at $80^{\circ} \mathrm{C}$ identified products of oxidative degradation such as ketones, carboxylic acids, and furanones. In another study of PE films, the levels of indicator products such as dicarboxylic acids were found to linearly correlate with the decrease in the molecular weight of the polymer (Hakkarainen \& Albertsson,
2005). Again, it should be noted that UV radiation is usually excluded from museums.

In a study of poly(ethylene terephthalate) (PET) granules, acetaldehyde and formaldehyde were shown to be emitted following thermal degradation at $200-300^{\circ} \mathrm{C}$, with a wider range of VOCs detected after degradation at higher temperatures (Dzieciol \& Trzeszczynski, 1998). Mixtures of low-molecular weight compounds extracted from samples of commercial rubber were shown by GC-MS analysis to contain small hydrocarbon fragments - evidence of polymer chain scission (Delaunay-Bertoncini et al., 2004).

A study of the semi-volatile organic compounds emitted from the samples of urea-formaldehyde and melamine-formaldehyde that were degraded at $70-300^{\circ} \mathrm{C}$ identified fatty acid lubricants, phthalate plasticizers, and degradation products such as amines, amides, and ureas (Watanabe et al., 2007). 
Table 3 Summarized results of reviewed research showing how detection of VOC emissions can be used to provide evidence of degradation, and to monitor degradation progress

\begin{tabular}{|c|c|c|c|c|c|c|}
\hline Polymer & Object & $\begin{array}{l}\text { Analytical } \\
\text { method }\end{array}$ & Diagnostic compounds & $\begin{array}{l}\text { Information } \\
\text { provided }\end{array}$ & Notes & Reference \\
\hline PE & Thin films & SPME-GC-MS & Carboxylic acids, ketones, furanones & $\begin{array}{l}\text { Evidence of } \\
\text { degradation }\end{array}$ & Products of oxidative degradation & $\begin{array}{l}\text { Hakkarainen et al. } \\
\text { (1997) }\end{array}$ \\
\hline PE & Polyethylene films & $\begin{array}{l}\text { Solvent extraction } \\
\quad \text { and GC-MS* }\end{array}$ & Dicarboxylic acids & $\begin{array}{l}\text { Degradation } \\
\text { progress }\end{array}$ & $\begin{array}{l}\text { Linear correlation between levels of } \\
\text { dicarboxylic acids and no. of chain } \\
\text { scissions following photooxidation }\end{array}$ & $\begin{array}{l}\text { Hakkarainen \& } \\
\text { Albertsson (2005) }\end{array}$ \\
\hline PET & $\begin{array}{l}\text { Granules for bottle } \\
\text { processing }\end{array}$ & GC analysis & Acetaldehyde, formaldehyde ${ }^{* *}$ & $\begin{array}{l}\text { Evidence of } \\
\text { degradation }\end{array}$ & Products of thermal degradation & $\begin{array}{l}\text { Dzieciol \& } \\
\quad \text { Trzeszczynski } \\
(1998,2000)\end{array}$ \\
\hline Rubber & $\begin{array}{l}\text { Commercial } \\
\text { isobutylene/ } \\
\text { isoprene rubber }\end{array}$ & $\begin{array}{l}\text { Solvent extraction } \\
\quad \text { and GC-MS* }\end{array}$ & Branched hydrocarbon fragments & $\begin{array}{l}\text { Evidence of } \\
\text { degradation }\end{array}$ & Products of polymer chain scission & $\begin{array}{l}\text { Delaunay-Bertoncini } \\
\text { et al. (2004) }\end{array}$ \\
\hline $\begin{array}{l}\text { Melamine } \\
\text { formaldehyde }\end{array}$ & $\begin{array}{l}\text { Commercial powdered } \\
\text { sample }\end{array}$ & $\begin{array}{l}\text { Solvent extraction } \\
\quad \text { and GC-MS* }\end{array}$ & Amines and anilines & $\begin{array}{l}\text { Evidence of } \\
\text { degradation }\end{array}$ & Degradation of base polymer & Watanabe et al. (2007) \\
\hline $\begin{array}{l}\text { Urea } \\
\quad \text { formaldehyde }\end{array}$ & $\begin{array}{l}\text { Commercial powdered } \\
\text { sample }\end{array}$ & $\begin{array}{l}\text { Solvent extraction } \\
\quad \text { and GC-MS* }\end{array}$ & Amines, urea derivatives & $\begin{array}{l}\text { Evidence of } \\
\text { degradation }\end{array}$ & Degradation of base polymer & Watanabe et al. (2007) \\
\hline PDMS & $\begin{array}{l}\text { Silicone rubber } \\
\text { samples }\end{array}$ & SPME-GC/MS & Octamethylcyclotetrasiloxane $\left(D_{4}\right)$ & $\begin{array}{l}\text { Degradation } \\
\text { Progress }\end{array}$ & $\begin{array}{l}\text { Increased levels of } \mathrm{D}_{4} \text { with increased thermal } \\
\text { degradation }\end{array}$ & Hall \& Patel (2006) \\
\hline PS & $\begin{array}{l}\text { Commercial virgin } \\
\text { plastic samples }\end{array}$ & MAE-GC-MS & $\begin{array}{l}\text { Benzaldehyde, phenol, benzoic acid, } \\
\text { acetophenone }\end{array}$ & $\begin{array}{l}\text { Degradation } \\
\text { progress }\end{array}$ & $\begin{array}{l}\text { VOC levels increase with increased } \\
\text { degradation }\end{array}$ & Vilaplana et al. (2010) \\
\hline Nylon & Extruded sheets & SPME-GC-MS & $\begin{array}{l}\text { Amides, pentanoic acid, pyridine } \\
\text { derivatives }\end{array}$ & $\begin{array}{l}\text { Degradation } \\
\text { progress }\end{array}$ & $\begin{array}{l}\text { VOC levels increase with increased } \\
\text { degradation }\end{array}$ & $\begin{array}{l}\text { Groning \& } \\
\quad \text { Hakkarainen (2001) }\end{array}$ \\
\hline
\end{tabular}

*Solvent extraction as referred to in this review, covers several different methods for isolating VOCs from plastic or rubber samples. In some cases, a plastic sample is placed in container of solvent with or without heating, while another approach involves trapping VOCs from heated plastic or rubber samples in cooled solvent traps. A Soxhlet extractor can also be used. Evaporation of the solvent then takes place and concentrated samples are analyzed via GC-MS

${ }_{\star \star *}^{*}$ Formaldehyde was absorbed in water and analyzed colorimetrically as a complex with chromotropic acid. 
A study of the thermally degraded polydimethylsiloxane (PDMS) rubber samples using SPME-GCMS found a significant buildup of octamethylcyclotetrasiloxane (known as $\mathrm{D}_{4}$, where $\mathrm{D}$ refers to the dimethylsiloxane unit and 4 refers to the number of $\mathrm{Si}-\mathrm{O}$ bonds in the molecule) with increased degradation and the authors suggest that the sensitive measurement of $\mathrm{D}_{4}$ can be used to assess thermal degradation (Hall \& Patel, 2006). Work by Vilaplana et al. (2010) studied the evolution of different VOC emissions from commercial samples of high-impact polystyrene (HIPS) during thermal degradation. The relative abundance of compounds such as benzaldehyde and phenol increased over time with other compounds such as benzoic acid not appearing until later in the degradation phase (Fig. 6) - suggesting that benzoic acid could be used as a marker of more advanced degradation in PS.

SPME-GC-MS analysis of thermally degraded samples of nylon 6.6 identified a range of VOC emissions, including cyclopentanone derivatives, amides, and carboxylic acids (Groning \& Hakkarainen, 2001). Concentrations of cyclopentanone derivatives decreased over time, suggesting that these are products formed during high-temperature processing, rather than degradation products. The number of VOCs was found to increase upon increased degradation time and other compounds such as amides, pentanoic acid, and pyridine derivatives showed increased emissions over time.

In summary, these results show that the degradation of different polymers produce particular VOC emissions and that in some cases, the levels of these emissions have been shown to change with increased degradation. Analysis of these VOCs therefore provides evidence of degradation and enables degradation

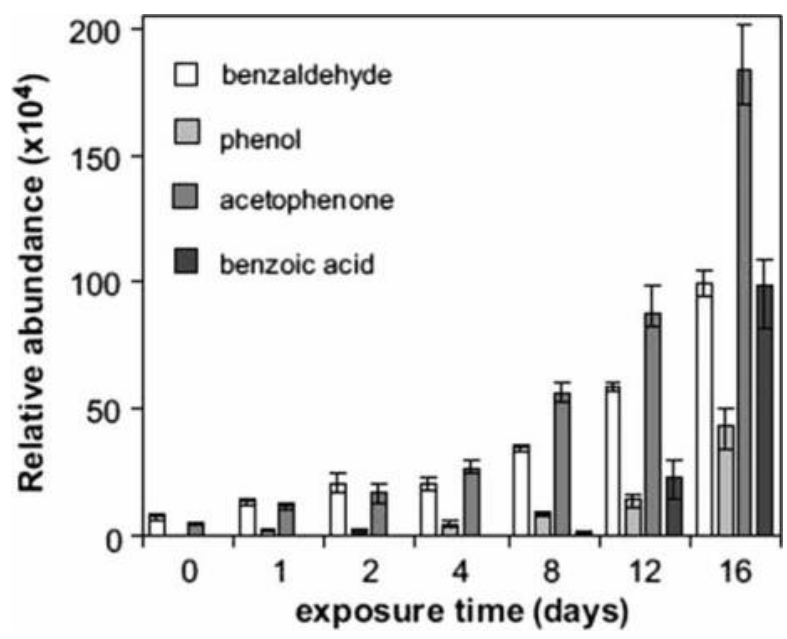

Figure 6 Relative abundance of detected low-molecular weight compounds from samples of HIPS following different periods of thermo-oxidative degradation. Reprinted from Vilaplana et al. (2010) with permission from Elsevier. progress to be monitored. In a heritage context, VOC analysis could lead to improved condition assessment and monitoring of degradation of a plastic or rubber object.

\section{Using VOC analysis for material identification}

VOC emissions can be very characteristic of a given material, and can provide detailed information about the presence or absence of specific additives and the identity of the base polymer. In addition, some analytical techniques such as SPME-GC-MS have the potential to be entirely non-destructive and non-contact, making VOC analysis very suitable for applications within conservation. The table below (Table 4) summarizes the previous research in which characteristic VOC emissions from different materials have been identified, and the VOC analysis has been used for material identification and to distinguish between different material formulations. Some of the data are taken from the ongoing project Heritage Smells!, a collaborative project in which the authors are exploring the VOC emissions of historical plastics and other materials.

The previously mentioned investigation by Sutherland et al. (2012) of the Naum Gabo sculpture Construction in Space: Two Cones (1927) demonstrates the advantage of using VOC analysis for material identification in addition to spectroscopic techniques. Due to the extensive degradation that had taken place, FTIR spectroscopy gave ambiguous results, suggesting that certain parts of the sculpture were made of cellulose. The identification using Py-GCMS of acetylated compounds positively identified those parts of the sculpture as being composed of CA that had deacetylated over time. For other parts of the sculpture, the Py-GC-MS studies corroborated the FTIR analysis and identified one of the other construction materials as $\mathrm{CN}$.

Other typical VOC emissions from CA include acetic acid and plasticizers. SPME-GC-MS analysis of a CA-based doll as part of the Heritage Smells! project detected acetic acid, phenol, known to be formed from the degradation of the plasticizer triphenyl phosphate (Shinagawa et al., 1992) and plasticizers such as dimethyl phthalate (DEM) and diethyl phthalate (DEP).

Py-GC-MS was used to characterize cellulose ester plastics (Schilling et al., 2010). It was possible to distinguish between ResinKit ${ }^{\mathrm{TM}}$ samples of CA, CA propionate, and $\mathrm{CA}$ butyrate through the detection of the characteristic organic acids emitted (acetic acid, propionic acid, and butanoic acid, respectively). Plasticizers and additives such as phthalates and triphenyl phosphate were also detected.

VOC analysis has also been used previously to distinguish between different $\mathrm{CA}$ formulations. In a 
study of CA-laminated documents using direct immersion-SPME-GC-MS, different brands of lamination films used between the 1940s and the 1980s in the National Archives and Records Administration could be distinguished from one another depending on the additives that were detected. The compounds detected were the plasticizers bis(2-methoxyethyl) phthalate (BMEP), DEP, DMP, and triphenylphosphate (TPP), and the UV absorber resorcinol monobenzoate (Ormsby, 2005).

An examination of U-matic videotapes from 1975 to 1997 performed by Thiébaut et al. (2009) also demonstrates the usefulness of VOC analysis in distinguishing between different polymer formulations. The tapes consisted of poly(ethylene terephthalate) films with polyester/PUR-based coatings. Using SPM-GC-MS, it was possible to identify the constituents of the PUR components; for example, the detection of toluene-diamine indicated that toluene diisocyanate was used in the synthesis of the hard polymer block. Using this method, 29 different sample films were divided into eight categories, based on their formulations (Table 4).

The most distinctive emissions from $\mathrm{CN}$ objects are the plasticizer camphor and its derivatives, such as fenchone and camphene, as shown in results from Lattuati-Derieux et al. (2012) and the Heritage Smells! project. Py-GC-MS of an unplasticized sample of $\mathrm{CN}$ showed the presence of characteristic products of cellulose degradation such as acetic acid and furfural, in addition to $\mathrm{N}_{2} \mathrm{O}$ (major product), a cresol isomer, 1H-indol, and 2,5-pyrrolidindione (Schwarzinger et al., 2001).

Studies of the VOC emissions from PVC samples have identified a wide range of compounds such as aliphatic hydrocarbons, alcohols such as ethanol and butoxyethanol, and additives such as the plasticizer di(2-ethyl hexyl)phthalate (DEHP) and 2,2,4-trimethyl-1,3-pentanediol diisobutyrate (TXIB), the antioxidant butylated hydroxytoluene, and alkyl benzenes, which are commonly used stabilizers used in PVC (Lundgren et al., 1999; Shashoua, 2001; Jarnstrom et al., 2007).

A key VOC marker compound for PMMA is the monomer, MMA. This was found to be the case for both degraded and non-degraded samples. This is shown in SPME-GC-MS analysis by Rogalewicz and Voelkel (2005) of thermally degraded commercial samples of PMMA, SPME-GC-MS analysis of PMMA objects as part of the Heritage Smells! project, and in work by Lattuati-Derieux et al. (2012). PMMA is known to depolymerize to MMA at elevated temperatures (Grassie \& Scott, 1988, p. 25). It is also possible that MMA emissions are residual material from the manufacturing process.
A recent study used HS-SPME-GC-MS to analyze recycled and virgin PET pellets and flakes used in plastic packaging processing (Dutra et al., 2011). Although more VOCs were emitted from the recycled materials, due to contamination from previous use, a wide range of compounds were also emitted from the virgin materials, including toluene, xylene, and 2,6-di-tert-butyl-hydroxytoluene (BHT), an antioxidant.

SPME-GC-MS analysis of PS samples as part of the Heritage Smells! project has identified styrene, ethylbenzene, and 1-methyl-ethyl-benzene as characteristic VOC emissions. The recent paper by LattuatiDerieux et al. (2012) identifies similar compounds. HS-SPME-GC-MS analysis of samples of crumbled expanded PS also showed the presence of pentane (used as a blowing agent for foam production), in addition to ethylbenzene and styrene (Kusch \& Knupp, 2004).

Research as part of the Heritage Smells! project has shown that at room temperature, phenol is emitted from samples of Bakelite and can be detected via SPME-GC-MS. This may be a degradation product, or possibly residual starting material. VOC emissions at high temperature have also been studied using Py-GC-MS (Shedrinsky et al. 1993). Six major compounds were identified following pyrolysis at $650^{\circ} \mathrm{C}$, phenol, $o$-cresol, $p$-cresol, 2,6-dimethylphenol, 2,4-dimethylphenol, and 2,4,6-trimethylphenol. These are likely to be the products of the degradation of the highly cross-linked Bakelite polymer structure (Cohen \& Aizenshtat, 1992).

Analysis of VOCs has also been used to distinguish between different types of rubber. A study of the pyrolysis products from waste tires showed that thermal degradation of poly(isoprene) rubber produced limonene and 1-methyl-4-(1-methylethyl)-benzene, while degradation of styrene-butadiene rubber produced styrene and 4-ethenylcyclohexene (Kwon \& Castaldi, 2009).

\section{Conclusions}

The analysis of VOC emissions from plastic and rubber materials has been performed across a wide range of fields, including conservation, polymer chemistry, construction, and waste management. As the examples shown in this review demonstrate, it is a very useful method for understanding polymer degradation and object damage, and for material identification. In addition, VOC analysis has the significant benefit of being a potentially non-destructive and entirely non-invasive technique, although it should be stressed that at present, many techniques rely on destructive sampling.

There are several examples where changes in the levels of specific VOC emissions can be related to deterioration, including loss of additives and 
Table 4 Summarized results of reviewed research showing identified VOC emissions for different materials

\begin{tabular}{|c|c|c|c|c|}
\hline Polymer & Object & Analytical method & VOC emissions & Reference \\
\hline CA & $\begin{array}{l}\text { Sculpture (Naum Gabo, } \\
\text { Construction in Space: Two } \\
\text { Cones, 1927) }\end{array}$ & Py-GC-MS & Acetylated anhydrosugars, AMF & $\begin{array}{l}\text { Sutherland et al. } \\
\text { (2012) }\end{array}$ \\
\hline CA & 'Ladybrush' Doll & SPME-GC-MS & Acetic acid, phenol, dimethyl, and DEP & $\begin{array}{l}\text { Curran, Underhill } \\
\text { et al. (2013) }\end{array}$ \\
\hline $\begin{array}{l}\text { CA, CAP, } \\
\text { CAB }\end{array}$ & $\begin{array}{l}\text { Screwdriver and handles, } \\
\text { knitting needle, ResinKit }{ }^{\top M}{ }^{*}\end{array}$ & Py-GC-MS & $\begin{array}{l}\text { Organic acids, dimethyl and DEP, adipate } \\
\text { esters, TPP, } N \text {-ethyl-p-toluenesulfonamide }\end{array}$ & $\begin{array}{l}\text { Schilling et al. } \\
\qquad(2010)\end{array}$ \\
\hline CA & Laminated documents & SPME-GC-MS & $\begin{array}{l}\text { BMEP, DEP, DMP, TPP, resorcinol } \\
\text { monobenzoate }\end{array}$ & Ormsby (2005) \\
\hline PUR & U-matic videotapes & SPM-GC-MS & $\begin{array}{l}\text { 1,4-butanediol, toluene-diamine, 4,4'- } \\
\text { methylenebis-benzenediamine, 3,3'- } \\
\text { tolidene-4,4'-diamine }\end{array}$ & $\begin{array}{l}\text { Thiébaut et al. } \\
\text { (2009) }\end{array}$ \\
\hline $\mathrm{CN}$ & Ping-pong balls & SPME-GC-MS & Camphor, camphene, fenchone, borneol & $\begin{array}{l}\text { Lattuati-Derieux } \\
\text { et al. (2012) }\end{array}$ \\
\hline CN & Jewellery boxes, vanity set & SPME-GC-MS & $\begin{array}{l}\text { Camphor and derivatives, e.g. 2,2,3- } \\
\text { trimethyl-bicyclo[2.2.1]heptane, } \\
\text { fenchone }\end{array}$ & $\begin{array}{l}\text { Curran, Underhill } \\
\text { et al. (2013) }\end{array}$ \\
\hline $\mathrm{CN}$ & $\begin{array}{l}\text { Newly synthesized, non- } \\
\text { plasticised sample }\end{array}$ & Py-GC-MS & $\begin{array}{l}\mathrm{N}_{2} \mathrm{O} \text {, acetic acid, furfural, furanone, cresol } \\
\text { isomer, } 1 \mathrm{H} \text {-indol }\end{array}$ & $\begin{array}{l}\text { Schwarzinger } \\
\text { et al. (2001) }\end{array}$ \\
\hline PVC & Flooring materials & $\begin{array}{l}\text { Field and Laboratory } \\
\text { Cell (FLEC) and } \\
\text { TD-GC-MS }\end{array}$ & Aliphatic hydrocarbons, esters, ketones & $\begin{array}{l}\text { Jarnstrom et al. } \\
\quad(2007)\end{array}$ \\
\hline PVC & Flooring materials & $\begin{array}{l}\text { FLEC and TD-GC- } \\
\text { MS }\end{array}$ & $\begin{array}{l}\text { 2-(2-butoxy-ethoxy) ethanol, butoxyethanol, } \\
\text { 2-ethyl-hexanol, phenol plasticizers, e.g. } \\
\text { TXIB, alkyl benzenes }\end{array}$ & $\begin{array}{l}\text { Lundgren et al. } \\
\text { (1999) }\end{array}$ \\
\hline PVC & $\begin{array}{l}\text { Commercial, plasticized } \\
\text { samples, had been } \\
\text { degraded at } 70^{\circ} \mathrm{C} \text { for } 65 \\
\text { days }\end{array}$ & HS-GC-MS & Plasticizers: DEHP, TXIB, alkyl benzenes & Shashoua (2001) \\
\hline PMMA & $\begin{array}{l}\text { Commercial samples, } \\
\text { thermally decomposed at } \\
100-280^{\circ} \mathrm{C} \text { for } 10 \text { minutes }\end{array}$ & SPME-GC-MS & MMA & $\begin{array}{l}\text { Rogalewicz \& } \\
\text { Voelkel (2005) }\end{array}$ \\
\hline PMMA & Transparent purple object & SPME-GC-MS & MMA & $\begin{array}{l}\text { Curran, Underhill } \\
\text { et al. (2013) }\end{array}$ \\
\hline PMMA & ResinKit ${ }^{T M} *$ & SPME-GC-MS & MMA & $\begin{array}{l}\text { Lattuati-Derieux } \\
\text { et al. (2012) }\end{array}$ \\
\hline PET & Plastic packaging & SPME-GC-MS & Toluene, xylene, BHT & Dutra et al. (2011) \\
\hline PS & Green cup & SPME-GC-MS & Styrene, ethylbenzene & $\begin{array}{l}\text { Curran, Underhill } \\
\text { et al. (2013) }\end{array}$ \\
\hline PS & ResinKit ${ }^{\mathrm{TM}} *$ & SPME-GC-MS & Styrene, ethylbenzene, methylstyrene & $\begin{array}{l}\text { Lattuati-Derieux } \\
\text { et al. (2012) }\end{array}$ \\
\hline PS & Polystyrene foam & SPME-GC-MS & Styrene, ethylbenzene, pentane & $\begin{array}{l}\text { Kusch \& Knupp } \\
\quad(2004)\end{array}$ \\
\hline Bakelite & Dark solid material & SPME-GC-MS & Phenol & $\begin{array}{l}\text { Curran, Underhill } \\
\text { et al. (2013) }\end{array}$ \\
\hline Bakelite & Bakelite 'amber' forgeries & Py-GC-MS & $\begin{array}{l}\text { Phenol, o-cresol, p-cresol, 2,6- } \\
\text { dimethylphenol, 2,4-dimethylphenol, and } \\
\text { 2,4,6-trimethylphenol }\end{array}$ & $\begin{array}{l}\text { Shedrinsky et al. } \\
\text { (1993) }\end{array}$ \\
\hline Rubber & $\begin{array}{l}\text { Waste tires (poly(isoprene) } \\
\text { rubber and styrene- } \\
\text { butadiene rubber) }\end{array}$ & TGA-GC-MS & $\begin{array}{l}\text { Limonene, 1-methyl-4-(1-methylethyl)- } \\
\text { benzene (poly(isoprene) }\end{array}$ & $\begin{array}{l}\text { Kwon \& Castaldi } \\
\quad(2009)\end{array}$ \\
\hline
\end{tabular}

${ }^{*}$ ResinKitTM samples are from the 'Complete Guide to Identifying and Testing Plastic Resins Polymer' produced by the RESINKITTM company (Woonsocket, RI, USA).

polymer degradation, and further research into the use of VOC 'markers' of degradation would be of interest. The use of acetic acid as a degradation marker for CA has been known for some time, and the products such as A-D strips for acetic acid detection are well established. However, further exploration of, for example, the use of benzoic acid as a marker of degradation in
PS, of acetaldehyde as a degradation marker of PET, or of amides as evidence of degraded nylon 6.6 would be of interest. In some cases, VOC emissions can be related to macroscopic 'damage', such as the increased levels of glycol derivatives detected from photolytically degraded samples of PUR ether foams that displayed discoloration and crumbling, or the 
link between carboxylic acid emissions and rancid odors from natural rubber samples.

In the case of material identification, techniques such as SPME-GC-MS allow for the unambiguous detection of additives such as phthalate plasticizers and antioxidants, e.g. butylated hydroxytoluene. The example of the Naum Gabo sculpture clearly demonstrates the advantage of using the VOC analysis for material identification where spectroscopy gives unclear results. VOC analysis has also been shown to distinguish between different polymer types and material formulations, for example, in the cases of rubber, cellulose ester-based polymers, and videotape formulations. While conservators have used characteristic odors to identify different plastics for many years, this method is quite subjective, and a more quantitative analysis of characteristic VOC 'signatures' of different materials could be useful for material identification purposes.

In general, a useful area for further research would be a more detailed quantitative analysis of particular VOC emissions from plastic artifacts. More knowledge of the concentrations of VOC emissions from degrading objects, their impact on indoor pollution, and on the comparison between different analytical methods would certainly be of interest.

In summary, while there is a significant amount of research to date on the topic of VOC emissions and polymer degradation across several fields, there is currently a wide scope for further research targeted at the needs of the heritage sector which would go some way toward addressing the needs for 'improved monitoring of the degradation of modern materials and for better identification of plastics' identified in the strategy documents. This review aims to bring together relevant work from a range of disciplines in order to prompt ideas for future research projects with the overall goal of improving the conservation of plastic and rubber artifacts.

\section{Acknowledgments}

The authors would like to acknowledge Colin Williamson for generously allowing the use of the image in Fig. 1 and Joe Mikuliak and Ken Sutherland for the use of Fig. 3. The work has been funded by UK AHRC/EPSRC Science and Heritage Programme (project Heritage Smells!, AH/ H032630/1).

\section{References}

Albertsson, A.-C., Gröning, M. \& Hakkarainen, M. 2006. Emission of Volatiles from Polymers - A New Approach for Understanding Polymer Degradation. Journal of Polymers and the Environment, 14: 9-13.

ASTM International. 2011. Standard Test Methods for Volatile Loss From Plastics Using Activated Carbon [accessed 4 October 2013]. Available at: <http://www.astm.org/Standards/D1203. htm>
Bigourdan, J. \& Reilly, J.M. 2000. Effectiveness of Storage Conditions in Controlling the Vinegar Syndrome: Preservation Strategies for Acetate Base Motion-Picture Film Collections. In: M. Aubert \& R. Billeaud, eds. Image and Sound Archiving and Access: The Challenges of the 3rd Millennium, Proceedings of the Joint Technical Symposium. Paris: Centre national du cinema et de l'image animee (CNC), pp. 14-34

Calmes, A. 1991. Plastics Found in Archives. In: D.W. Grattan, ed. Saving the Twentieth Century: The Conservation of Modern Materials, Proceedings of a Conference Symposium'91. Ottawa: Canadian Conservation Institute, pp. 95-102.

Carlsson, D.J., Krzymien, M.E., Pleizier, G., Worsfold, D.J. \& Day, M. 1999. Volatiles Released from PVC during Photochemical Degradation. The Fate of Chlorine. In: Society of Plastics Engineers (SPE), Vinyl Challenges: Processing Formulations and our responsibilities: Proceedings of the Technical Conference of the Society of Plastic Engineers (Vinyltec 99). Toronto: Vinyl Council of Canada, pp. 8-12

Cohen, Y. \& Aizenshtat, Z. 1992. Investigation of Pyrolytically Produced Condensates of Phenol-Formaldehyde Resins, in Relation to their Structure and Decomposition Mechanism. Journal of Analytical and Applied Pyrolysis, 22: 153-78.

Curran, K., Mozir, A., Underhill, M., Gibson, L.T., Fearn, T. \& Strlič, M. 2013. Cross-Infection Effect of Polymers of Historic and Heritage Significance on the Degradation of a Cellulose Reference Test Material. Polymer Degradation and Stability, http://dx.doi.org/10.1016/j.polymdegradstab.2013.12.019.

Curran, K., Underhill, M., Gibson, L. \& Strlič, M. 2013. Heritage Smells! Analysis of VOC Emissions from Historic Plastics Using SPME-GC/MS. 5 June [presentation]. Pisa: 6th Users' Group for Mass Spectrometry and Chromatography Meeting.

- Delaunay-Bertoncini, N., van der Wielen, F.W.M., de Voogt, P., Erlandsson, B. \& Schoenmakers, P.J. 2004. Analysis of LowMolar-Mass Materials in Commercial Rubber Samples by Soxhlet and Headspace Extractions Followed by GC-MS Analysis. Journal of Pharmaceutical and Biomedical Analysis, 35: 1059-73.

Dutra, C., Pezo, D., Freire, M.T.D.A., Nerín, C. \& Reyes, F.G.R. 2011. Determination of Volatile Organic Compounds in Recycled Polyethylene Terephthalate and High-Density Polyethylene by Headspace Solid Phase Microextraction Gas Chromatography Mass Spectrometry to Evaluate the Efficiency of Recycling Processes. Journal of Chromatography A, 1218: $1319-30$.

Dzieciol, M. \& Trzeszczynski, J. 1998. Studies of Temperature Influence on Volatile Thermal Degradation Products of Poly(ethylene terephthalate). Journal of Applied Polymer Science, 69: 2377-81.

Dzieciol, M. \& Trzeszczynski, J. 2000. Volatile Products of Poly(ethylene terephthalate) Thermal Degradation in Nitrogen Atmosphere. Journal of Applied Polymer Science, 77: 1894-1901.

European Parliament, Council. 2004. Directive 2004/42/CE of the European Parliament and of the Council of 21 April 2004 on the Limitation of Emissions of Volatile Organic Compounds Due to the Use of Organic Solvents in Certain Paints and Varnishes and Vehicle Refinishing Products and Amendi [accessed 28 September 2013]. Available at: <http://eur-lex. europa.eu/LexUriServ/LexUriServ.do?uri=CELEX:32004L00 42:EN:NOT>

Fenn, J. 1995. The Cellulose Nitrate Timebomb: Using Sulphonephthalein Indicators to Evaluate Storage Strategies. In: J. Heumann, ed. Postprints Tate Gallery Conference 'From Marble to Chocolate'. The Conservation of Modern Sculpture. London: Archetype, pp. 87-92.

Grassie, N. \& Scott, G. 1988. Polymer Degradation and Stabilisation. Cambridge: Cambridge University Press.

Groning, M. \& Hakkarainen, M. 2001. Headspace Solid-Phase Microextraction - A Tool for New Insights into the Longterm Thermo-oxidation Mechanism of Polyamide 6.6. Journal of Chromatography A, 932: 1-11.

Hakkarainen, M. \& Albertsson, A.-C. 2005. Indicator Products: A New Tool for Lifetime Prediction of Polymeric Materials. Biomacromolecules, 6: 775-9.

Hakkarainen, M., Albertsson, A.-C. \& Karlsson, S. 1997. Solid Phase Microextraction (SPME) as an Effective means to Isolate Degradation Products in Polymers. Journal of Environmental Polymer Degradation, 5: 67-73.

Hall, A.D. \& Patel, M. 2006. Thermal Stability of Foamed Polysiloxane Rubbers: Headspace Analysis using Solid Phase 
Microextraction and Analysis of Solvent Extractable Material using Conventional GC-MS. Polymer Degradation and Stability, 91: 2532-9.

-Harthan, J.C., Edge, M., Allen, N.S. \& Bodner, M. 1997. The Development and Evaluation of a Sensory System to Detect Degradation in Cellulose Triacetate Photographic Film. Part II: Selection of a Solid Support for the Indicator and Field Trials on Indicator Performance. Imaging Science Journal, 45: 81-3.

Hoven, V.P., Rattanakaran, K. \& Tanaka, Y. 2003. Determination of Chemical Components that Cause Mal-Odor from Natural Rubber. Rubber Chemistry and Technology, 76: 1128-44.

Image Permanence Institute. 2001. User's Guide for A-D Strip [accessed 4 October 2013]. Available at: <https://www.image permanenceinstitute.org/webfm_send/309>

Jarnstrom, H., Saarela, K., Kalliokoski, P. \& Pasanen, A.-L. 2007. Reference Values for Structure Emissions Measured on Site in New Residential Buildings in Finland. Atmospheric Environment, 41: 2290-302.

Keneghan, B., Richardson, E., Rivenc, R., de Groot, S., van Oosten, T., Cucci, C., Bacci, M., Kolar, J. \& Kolesa, D. 2012. Chemical Composition/Structural Characterisation Using Spectroscopic Techniques. In: B. Lavedrine, A. Fournier \& G. Martin, eds. Preservation of Plastic Artefacts in Museum Collections. Paris Editions du Comite des travaux historiques et scientifiques, pp. $43-57$.

Keneghan, B., van Oosten, T., Lagana, A., Wagenaar, M., Barabant, G., Balcar, N., Bluzat, H., Bollard, C., Fayein, J. Kuperholc, S., Ramel, S. \& Lattuati-Derrieux, A. 2012. In What Condition are my Artefacts? Case Studies. In: B. Lavedrine, A. Fournier \& G. Martin, eds. Preservation of Plastic Artefacts in Museum Collections. Paris: Editions du Comite des travaux historiques et scientifiques, pp. 109-37.

Kusch, P. \& Knupp, G. 2004. Headspace-SPME-GC-MS Identification of Volatile Organic Compounds Released from Expanded Polystyrene. Journal of Polymers and the Environment, 12: 83-7.

Kwon, E. \& Castaldi, M.J. 2009. Fundamental Understanding of the Thermal Degradation Mechanisms of Waste Tires and Their Air Pollutant Generation in a N2 Atmosphere. Environmental Science and Technology, 43: 5996-6002.

Lattuati-Derieux, A., Egasse, C., Thao-Heu, S., Balcar, N., Barabant, G. \& Lavédrine, B. 2012. What Do Plastics Emit? HS-SPME-GC/MS Analyses of New Standard Plastics and Plastic Objects in Museum Collections. Journal of Cultural Heritage, 14: 238-47.

Lattuati-Derrieux, A., Thao, S., Langlois, J. \& Regert, M. 2008. First Results on Headspace-Solid Phase Microextraction-Gas Chromatography/Mass Spectrometry of Volatile Organic Compounds Emitted by Wax Objects in Museums. Journal of Chromatography A, 1187: 239-49.

Lattuati-Derrieux, A., Thao-Heu, S. \& Lavedrine, B. 2011. Assessment of the Degradation of Polyurethane Foams after Artificial and Natural Ageing by using Pyrolysis-Gas Chromatography/Mass Spectrometry and Headspace-Solid Phase Microextraction-Gas Chromatography/Mass Spectrometry. Journal of Chromatography A, 1218: 4498-508.

Lundgren, B., Jonsson, B. \& Ek-Olausson, B. 1999. Materials Emission of Chemicals - PVC Flooring Materials. Indoor Air, 9: $202-8$

Luxford, N., Strlič, M. \& Thickett, D. 2013. Safe Display Parameters for Veneer and Marquetry Objects: A Review of the Available Information for Wooden Collections. Studies in Conservation, 58: 1-12.

Marek, B. \& Lerch, E. 1965. Photodegradation and Yellowing of Polyamides. Journal of the Society of Dyers and Color, 81: 481-7.

Mossman, S. 1988. Simple Methods of Identifying Plastics. In: L. Eaton \& C. Meredith, eds. Modern Organic Materials, Preprints of the Meeting of the Scottish Society for Conservation and Restoration. Edinburgh: Scottish Society for Conservation and Restoration, pp. 41-5.

Mossman, S. 1991. Plastics in the Science Museum, London: A Curator's View. In: D.W. Grattan, ed. Saving the Twentieth Century: The Conservation of Modern Materials, Proceedings of a Conference Symposium '91. Ottawa: Canadian Conservation Institute, pp. 25-35.
Ormsby, M. 2005. Analysis of Laminated Documents Using SolidPhase Microextraction. Journal of the American Institute for Conservation, 44: 13-26.

Rogalewicz, R. \& Voelkel, A. 2005. HS-SPME-GC-MS Analysis of Organic Compounds Emitted from Poly(methyl methacrylate). Chemia Analityczna, 50: 991-1006.

Schilling, M., Bouchard, M., Khanjian, H., Learner, T., Phenix, A. \& Rivenc, R. 2010. Application of Chemical and Thermal Analysis Methods for Studying Cellulose Ester Plastics. Accounts of Chemical Research, 43: 888-96.

Schilling, M., Rivenc, R., Balcar, N. \& van Keulen, H. 2012. Pyrolysis Gas Chromatography Mass Spectrometry. In: B. Lavedrine, A. Fournier \& G. Martin, eds. Preservation of Plastic Artefacts in Museum Collections. Paris: Editions du Comite des travaux historiques et scientifiques, pp. 61-9.

Schwarzinger, C., Tanczos, I. \& Schmidt, H. 2001. Pyrolysis-Gas Chromatography/Mass Spectrometry and Thermally Assisted Hydrolysis and Methylation (THM) Analysis of Various Cellulose Esters. Journal of Analytical and Applied Pyrolysis, 58-59: 513-23.

Shashoua, Y. 2001. Inhibiting the Deterioration of Plasticized Poly(vinyl chloride) - A Museum Perspective. PhD Thesis, The Technical University of Denmark.

Shashoua, Y. 2008. Conservation of Plastics. Oxford: Elsevier.

Shashoua, Y. \& Ward, C. 1995. Plastics: Modern Resins with Ageing Problems. In: M.M. Wright \& J.H. Townsend, eds. Resins Ancient and Modern: Pre-prints of the Conference held at The Department of Zoology, University of Aberdeen. Aberdeen: The Scottish Society for Conservation \& Restoration. pp. 33-7.

Shedrinsky, A.M., Grimaldi, D.A., Boon, J.J. \& Baer, N.S. 1993. Application of Pyrolysis-Gas Chromatography and PyrolysisGas Chromatography/Mass Spectrometry to the Unmasking of Amber Forgeries. Journal of Analytical and Applied Pyrolysis, 25: 77-95.

Shinagawa, Y., Murayama, M. \& Sakaino, Y. 1992. Investigation of the Archival Stability of Cellulose Triacetate Film: The Effect of Additives to CTA Support. In: N.S. Allen, M. Edge \& C.V. Horie, eds. Postprints of Polymers in Conservation. Manchester: Royal Society of Chemistry, pp. 138-50.

-Strlič, M., Thomas, J., Trafela, T., Cséfalvayová, L., Kralj Cigić, I., Kolar, J. \& Cassar, M. 2009. Material Degradomics: On the Smell of Old Books. Analytical Chemistry, 81: 8617-22.

Stuart, B. 2007. Analytical Techniques in Materials Conservation. Chichester: John Wiley \& Sons Ltd.

-Sutherland, K., Schwarzinger, C. \& Price, B.A. 2012. The Application of Pyrolysis Gas Chromatography Mass Spectrometry for the Identification of Degraded Early Plastics in a Sculpture by Naum Gabo. Journal of Analytical and Applied Pyrolysis, 94: 202-8.

Then, E. \& Oakley, V. 1993. A Survey of Plastic Objects at the Victoria \& Albert Museum. Conservation Journal, 6: 11-4.

Thiebaut, B., Lattuati-Derrieux, A., Hocevar, M. \& Leon-Bavi, V. 2007. Application of Headspace SPME-GC-MS in Characterisation of Odorous Volatile Organic Compounds Emitted from Magnetic Tape Coatings Based on Poly(urethane-ester) after Natural and Artificial Ageing. Polymer Testing, 26: 243-56.

Thiébaut, B., Vilmont, L.-B. \& Lavédrine, B. 2009. Characterization of U-matic Videotape Deterioration by Size Exclusion Chromatography and Pyrolysis Gas Chromatography/Mass Spectrometry and the Role of Adipic Acid. Journal of Cultural Heritage, 10: 183-97.

-Vilaplana, F., Ribes-Greus, A. \& Karlsson, S. 2010. Chromatographic Pattern in Recycled High-Impact Polystyrene (HIPS) - Occurrence of Low Molecular Weight Compounds during the Life Cycle. Polymer Degradation and Stability, 95: 172-86.

-Watanabe, M., Nakata, C., Wu, W., Kawamoto, K. \& Noma, Y. 2007. Characterization of Semi-Volatile Organic Compounds Emitted during Heating of Nitrogen-containing Plastics at Low Temperature. Chemosphere, 68: 2063-72.

Williams, J. 2009. The Role of Science in the Management of the UK's Heritage. Bristol: National Heritage Science Strategy.

Williamson, C. 1999. Odour of Fumes. In: A. Quye \& C. Williamson, eds. Plastics Collecting and Conserving. Edinburgh: National Museums of Scotland, p. 67. 